Document downloaded from:

http://hdl.handle.net/10251/81008

This paper must be cited as:

Hidalgo Signes, C.; Garzón-Roca, J.; Martínez Fernández, P.; Garrido De La Torre, ME.; Insa Franco, R. (2016). Swelling potential reduction of Spanish argillaceous marlstone Facies Tap soil through the addition of crumb rubber particles from scrap tyres. Applied Clay Science. 132-133:768-773. doi:10.1016/j.clay.2016.07.027.

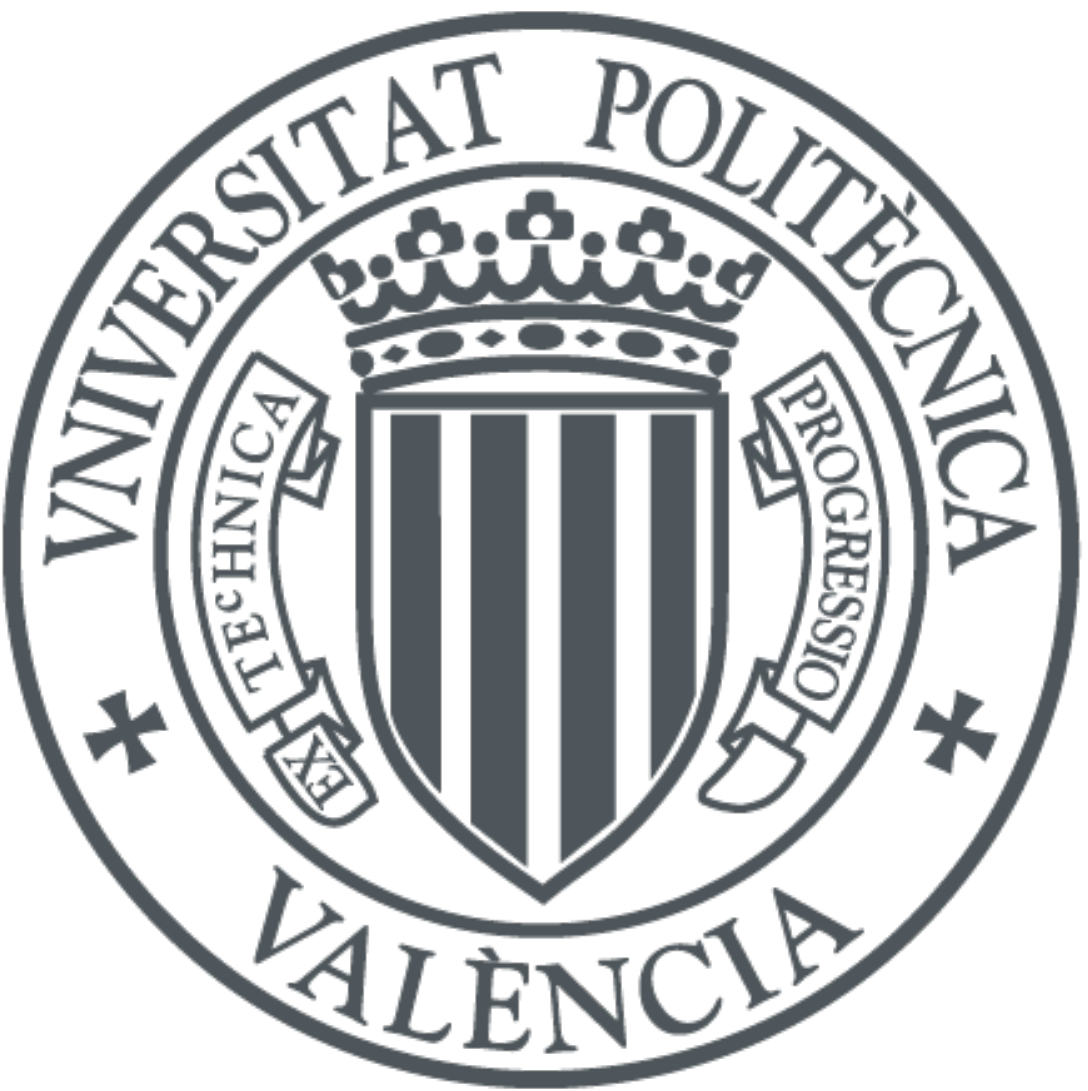

The final publication is available at

https://doi.org/10.1016/j.clay.2016.07.027

Copyright Elsevier

Additional Information 


\title{
SWELLING POTENTIAL REDUCTION OF SPANISH ARGILLACEOUS MARLSTONE FACIES \\ TAP SOIL THROUGH THE ADDITION OF CRUMB RUBBER PARTICLES FROM SCRAP TYRES
}

Carlos Hidalgo Signes ${ }^{\mathrm{a}, *}$, Julio Garzón-Roca ${ }^{\mathrm{a}}$, Pablo Martínez Fernández ${ }^{\mathrm{b}}$, Maria Elvira Garrido de la Torre Ricardo Insa Franco ${ }^{\mathrm{b}}$

a Department of Geotechnical and Geological Engineering, Universitat Politècnica de València, Valencia, Spain.

${ }^{\mathrm{b}}$ Department of Transport Engineering and Infrastructure, Universitat Politècnica de València, Valencia, Spain.

${ }^{*}$ Corresponding author. Tel.: +34 963877 000; fax: +34 963877 569; E-mail address: chidalgo@trr.upv.es

\begin{abstract}
During construction of road and railway projects, expansive soils may be encountered. Their use as construction material for embankments presents difficulties, due to their tendency to swell or shrink. Traditional solutions include mixing soil with cement or quicklime, or to import materials from other locations. As an alternative to these solutions, the present paper proposes a less expensive and more sustainable solution, consisting in mixing the natural expansive soil with rubber particles obtained from scrap tyres. Especially, the "Facies Tap" (a typical soil of southeastern Spain) is studied in this paper. This soil, which is mainly a white argillaceous marlstone, is mixed with six different amounts of rubber content $(2.5,5,10,15,20$ and $25 \%$ in terms of weight) and submitted to several geotechnical tests, including compaction, free swelling, unidimensional consolidation, direct shear testing and undrained shear compression. The addition of rubber particles to the soil up to a $15 \%$ makes it lighter and less prone to swelling, while compressibility remains similar to the natural soil and the drained shear strength slightly increases. Based on experimental results, the optimum rubber content mixed with the soil to prevent its swelling is established at around $3 \%$.
\end{abstract}

Keywords: scrap tyres; rubber-soil mix; expansive soil; swelling; embankment. 


\section{Introduction}

When a new road or railway is built, embankments represent one of the main and most expensive step of the construction project. In many cases, roads and railways pass through areas where expansive soils are encountered, making impossible the use of in situ natural soils as a construction material. This is a typical issue in Spain, where many southeastern clayey soils are prone to suffer from swelling and, as a consequence, they do not fulfil standard road or railway requirements (PG3; PGP-2008). Therefore, materials from other locations are required, or in situ natural soils have to be improved by cement-like materials or quicklime treatments (Nelson and Miller, 1992), the use of synthetic fibres (Akbulut et al., 2007) or geo-membranes (Steinberg, 1998). All of these solutions cause a significant increase in the cost of the project (Mahdi Hejazi et al., 2012). An alternative, that may result in a less expensive and more sustainable solution, consists in mixing the natural clayey soil with rubber particles obtained from scrap tyres.

Over the last few decades, many researchers focused on the application of scrap tyres on earthworks (ASTM D6270, 1998) as a way of waste management. It is important to note that scrap tyres represent a serious environmental threat as they are produced in large quantities and their disposal tends to be rather problematic. Studies demonstrated that rubber particles from scrap tyres can be mixed with soil, resulting in suitable material for being used in road embankments (Edil and Bosscher, 1994; Humphrey and Blumenthal, 2010), and even providing a certain degree of enhancement in the soil properties. The material resulting of mixing soil and rubber is lighter and less prone to swelling (Higuera Seda et al., 2007) due to the lower specific gravity of rubber (typically between 1.15 and 1.21) when compared to that of natural soils (typically between 2.55 and 2.75). Likewise, rubber particles was also applied to railways, as a layer completely made of tyre shreds (Wolfe et al., 2004), mixed with bitumen (Buonanno and Mele, 2000) as well as mixed with aggregates and soil (Benda, 1995; Hidalgo et al., 2015a; 2015b; Long et al., 1984; Trouzine et al., 2012). 
Hence, this paper studies the use of rubber particles obtained from scrap tyres to improve the soil properties of a typical clayey soil of the southeastern Spain named "Facies Tap", to its use as embankment. This material is basically a marine deposit made of white argillaceous marlstone, and is well-known by Spanish civil engineers due to its high degree of degradation, which creates stability problems when excavated, as well as its tendency to present swell, which makes difficult its use as construction material for embankments. To complete the soil geotechnical identification and its geological description, chemical and mineralogical study of the Facies Tap soil was conducted by X-ray diffraction (XRD) and X-ray fluorescence. In order to study the effect of the rubber particles addition on the soil behaviour, six mixes with different percentages of rubber $(2.5$, $5,10,15,20$ and $25 \mathrm{wt} \%$ ) were tested and compared to the natural soil (laboratory tests include compaction, free swelling, consolidation, direct shear and unconfined compression tests). The aim of the study is to evaluate an optimum content of added rubber considering the required properties for embankments.

\section{Materials}

\subsection{Clayey soil}

Samples were obtained according to the standard practice for sampling aggregates (ASTM D75/D75M-09) from several trenches located at the Spanish A-7 Highway near the town of "Muro de Alcoy", at around $90 \mathrm{~km}$ south from Valencia (Spain). Selected soil corresponds to the named "Facies Tap" (Fig. 1a), a marine deposit mainly composed by white argillaceous marlstone, with some content of organic clay and lignite. In its natural state, this soil tends to form aggregates that give to the soil the appearance of a granular soil. However, those aggregates have very low consistency and are easily crumbled.

\subsection{Rubber particles}

Rubber particles were obtained from scrap tyres and supplied by a Spanish company that is specialized in tyre recycling. Maximum particle size of rubber powder (on Fig. 1b) was $2 \mathrm{~mm}$ and 
steel from wires and metal particles (still present in rubber tyres) were removed to avoid the inclusion of any metallic element in soil-rubber mixes. As in the case of the soil, sampling of the rubber particles was carried out according to ASTM D75/D75M-09.

\subsection{Soil-rubber mixes}

Six mixes of cohesive soil and rubber particles (Fig. 1c) were prepared with varying percentages of rubber, namely $2.5,5,10,15,20$ and $25 \%$, in terms of weight (noted $\mathrm{x}$ wt $\%$ ). Mixes with rubber over $25 \%$ were not considered due to the high degree of bulking observed in such mixtures when moisture content was close to the Proctor optimum.

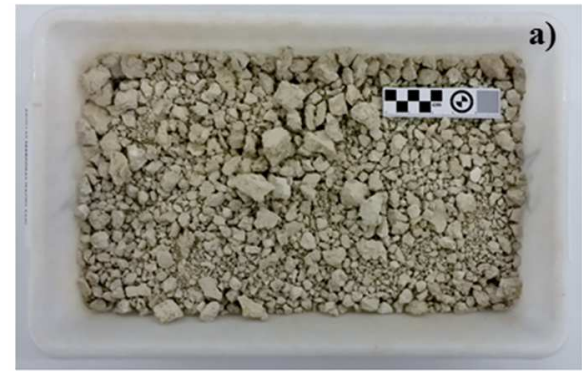

a)
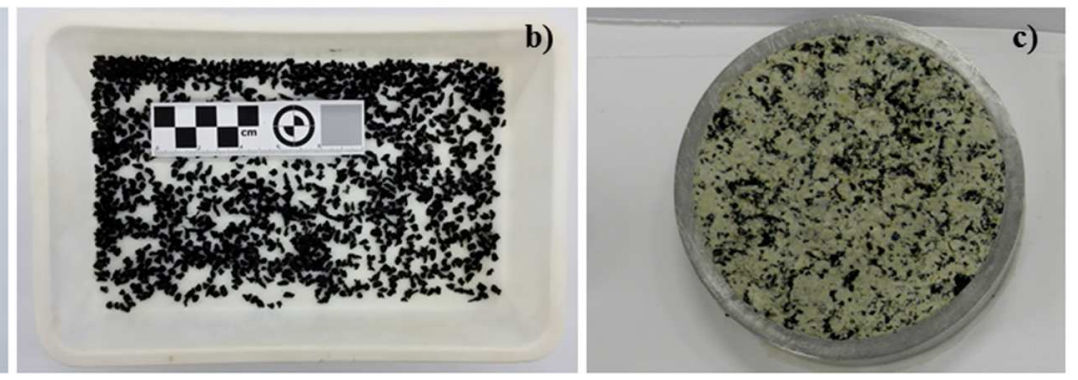

Fig. 1. Soil and rubber samples: (a) Soil; (b) Rubber particles; (c) Soil-rubber mixture (Scale bar in cm).

\section{Testing program}

\subsection{Mineralogy and chemical composition of the soil}

The soil was analysed using a D8 ADVANCE diffractometer from Bruker. Powder X-ray pattern was collected on $2-65^{\circ} 2 \theta$ range with a step of $0.02^{\circ} 2 \theta$ and a time acquisition of 0.7 seconds per step. To identify the clay mineralogy, a soil sample was decarbonated with hydrochloric acid and the $<2 \mu \mathrm{m}$ soil fraction was extracted by sedimentation in deionised water completed by ultrasounds dispersion. Afterwards, oriented glass slides were made and then analysed by X-ray diffraction. A semi-quantitative mineralogical analysis was made on the clay component by means of the reflective power method (Barahona, 1974). Clay mineral identification was conducted according to Środoń (1984) and Moore and Reynolds (1989). A semi-quantitative chemical analysis with X-ray fluorescence spectroscopy was then carried using a Bruker S2Ranger device while total carbon 
content was analysed using a SHIMADZU TOC-V (CSH) device equipped with a solid sample module SSM-5000A.

\subsection{Identification tests on soil and rubber particles}

Several geotechnical tests were conducted in both the soil sample and the rubber particles to fully characterize these materials. Those tests were carried out according to ASTM standards and included granulometry, Atterberg limits, specific density and water absorption (Table 1).

Table 1. Properties of soil and rubber particles.

\begin{tabular}{|c|c|c|c|c|}
\hline Parameters & Standard & Unit & $\begin{array}{l}\text { Cohesive soil } \\
\text { (Facies Tap) }\end{array}$ & Rubber particles \\
\hline Grain size & ASTM D6913 & & & \\
\hline Maximum particle size & & $\mathrm{mm}$ & - & 2.0 \\
\hline Gravel $(>5000 \mu \mathrm{m})$ & & $\%$ & 0.0 & 0.0 \\
\hline Sand $(80-5000 \mu \mathrm{m})$ & & $\%$ & 3.6 & 99.9 \\
\hline Fines $(<80 \mu \mathrm{m})$ & & $\%$ & 96.4 & 0.1 \\
\hline Sedimentation analysis & ASTM D7928 & & & \\
\hline Particles $<2 \mu \mathrm{m}$ & & $\%$ & 47.2 & - \\
\hline Atterberg Limits & ASTM D4318/ASTM D427 & & & \\
\hline Liquid Limit $\left(\mathrm{W}_{\mathrm{L}}\right)$ & & - & 52.2 & - \\
\hline Plastic Limit (WP) & & - & 24.1 & - \\
\hline Plasticity Index (PI) & & - & 28.1 & - \\
\hline Shrinkage Limit (SL) & & - & 13.4 & - \\
\hline Soil classification - USCS & ASTM D2487 & - & $\mathrm{CH}$ & - \\
\hline Specific gravity $\left(\mathrm{G}_{\mathrm{s}}\right)$ & ASTM D854 & - & 2.692 & 1.136 \\
\hline Water absorption & ASTM C127 & $\%$ & - & 5.0 \\
\hline Soluble salt & ASTM D4542 & $\%$ & 0.6 & - \\
\hline Calcium carbonate content & ASTM D4373 & $\%$ & 68.4 & - \\
\hline Organic matter content & ASTM D2974 & $\%$ & 0.2 & - \\
\hline
\end{tabular}

\subsection{Compaction tests}

Compaction tests were performed on natural soil and the soil-rubber mixes to obtain their maximum dry density and optimum moisture content. A Standard Proctor test (ASTM D698) and a Modified Proctor test (ASTM D1557) were carried out on each sample, analysing two different levels of compaction energy. Values of dry density and optimum moisture obtained from these tests were used as a reference to prepare the specimens for all the subsequent tests. 


\subsection{Free swelling tests}

A free swelling test based on ASTM D4546 was carried out on both the natural soil (an argillaceous marlstone) and the soil-rubber mixes. Conventional oedometric equipment with $70 \mathrm{~mm}$ (diameter) per $20 \mathrm{~mm}$ (height) oedometric ring was used to perform this test. Remoulded specimens were compacted up to $100 \%$ of Standard Proctor energy at the corresponding Standard Proctor optimum moisture content. Free swelling was assessed under a small constant load of $10 \mathrm{kPa}$ and by filling the testing cell with water once initial deformations were stabilised. Then, vertical deformation was measured and controlled every 10 seconds until stabilization (after at minimum 72 hours).

\subsection{Unidimensional consolidation tests}

A unidimensional consolidation test in oedometric conditions was carried out on both the natural soil and the soil-rubber mixes following ASTM D2435/D2435M-11 standard. The same oedometric equipment described for the free swelling test was used. Load increments of 5, 10, 20, 40, 80, 150, 300, 600 and $1000 \mathrm{kPa}$ were set for the loading path, while unloading decrements were set to 600, 300, 80, 20 and $5 \mathrm{kPa}$. The device was equipped with deformation sensors capable of measuring up to a $10 \mathrm{~mm}$ deformation with a $0.001 \mathrm{~mm}$ accuracy. Due to the swelling behaviour of the tested specimens, most of the tests during the saturation stage, had to be started and ended with a load corresponding to the swelling pressure of each mix.

\subsection{Direct shear tests}

Specimens of both natural soil and soil-rubber mixes were submitted to consolidated and drained (CD) direct shear tests, according to ASTM D3080/D3080M. A direct shear equipment with circular shear boxes of $50 \mathrm{~mm}$ of diameter and $25 \mathrm{~mm}$ of height was used. For the natural soil and each studied mix, three specimens were tested with different normal vertical stresses: 100, 200 and $300 \mathrm{kPa}$. All specimens were saturated during 24 hours before testing. After saturation, specimens were consolidated during 24 hours. Finally, a shear load was applied at a speed of $0.03 \mathrm{~mm} / \mathrm{min}$ 
until reaching a horizontal strain of $8 \mathrm{~mm}$ (maximum displacement of equipment). Failure was considered to be the shear stress corresponding to the $15 \%$ of shear deformation (Cetin et al., 2006).

\subsection{Unconfined compression tests}

Resistance to simple compression (Unconfined Compression Strength, hereafter UCS) of specimens of both natural soil and soil-rubber mixes was obtained according to ASTM D2166/D2166M-13. An electromechanical universal testing machine with axial deformation sensors was used. One cylindrical specimen for each mix (diameter $38.1 \mathrm{~mm}$; height $76.2 \mathrm{~mm}$ ), as well as for the natural soil, was manufactured and tested. Those specimens were compacted at $100 \%$ of the Modified Proctor energy, then put inside a plastic bag and stored during 24 hours in a humid chamber $(\% \mathrm{RH}$ > 95-100 and $\mathrm{T}{ }^{\circ} \mathrm{C}=20-25$ ) to homogenise moisture in specimen before testing. Specimens were tested under controlled deformation, at a speed of $0.76 \mathrm{~mm} / \mathrm{min}$ until either a $15 \%$ maximum axial strain was reached or the maximum stress level was achieved.

\section{Results}

\subsection{Mineralogy and chemical composition of the soil}

From powder X-ray diffraction pattern, the natural soil is basically composed of calcite, phyllosilicates (clay minerals), quartz and feldspar (plagioclase). The semi-quantitative mineralogical analysis results are listed in Table 2 . The marlstone is composed of up to $20 \%$ of smectite, which explains that the studied soil is very prone to swell in contact with water. Total carbon analysis yields a $8.6 \pm 0.8 \mu \mathrm{g}$ of carbon per $\mathrm{g}$ of soil, and $0.8 \mu \mathrm{g} / \mathrm{g}$ of such carbon is organic carbon. This confirms that the studied soil contains organic matter in typical content justifying that such soil belongs to the "Facies Tap" soils.

The chemical composition from X-ray fluorescence in Table $\mathbf{3}$ is in accordance with the mineralogy. The high amount of calcium is associated to calcite while silicon and aluminium are the main components of clay. The high amount of iron agrees with the presence of iron-rich smectite (nontronite). Besides, the presence of calcium is consistent with a plagioclase such as anorthite 
$\left(\mathrm{CaAl}_{2} \mathrm{Si}_{2} \mathrm{O}_{8}\right)$ and not albite. The magnesium and potassic content are related to the presence of palygorskite and illite, respectively.

Table 2. Determination of mineralogy by X-ray diffraction.

\begin{tabular}{llllllll}
\hline \multirow{2}{*}{ Mineralogy } & \multirow{2}{*}{ Calcite } & \multicolumn{2}{l}{ Phyllosilicates } & \multicolumn{3}{c}{ Quartz } & Plagioclase \\
\cline { 3 - 7 } & & Smectite & Palygorskite & Illite & Kaolinite & \\
\hline Content & $63.0 \%$ & $19.8 \%$ & $0.9 \%$ & $0.9 \%$ & $0.4 \%$ & $12.0 \%$ & $3.0 \%$ \\
\hline
\end{tabular}

Table 3. Chemical composition of the soil by X-ray fluorescence

\begin{tabular}{lllllllll}
\hline Composition in oxides & $\mathrm{CaO}$ & $\mathrm{SiO}_{2}$ & $\mathrm{Al}_{2} \mathrm{O}_{3}$ & $\mathrm{Fe}_{2} \mathrm{O}_{3}$ & $\mathrm{MgO}$ & $\mathrm{K}_{2} \mathrm{O}$ & $\mathrm{TiO}_{2}$ & others \\
\hline Content & $63.7 \%$ & $22.3 \%$ & $6.8 \%$ & $3.6 \%$ & $1.5 \%$ & $1.3 \%$ & $0.5 \%$ & $0.3 \%$ \\
\hline
\end{tabular}

\subsection{Geotechnical identification}

Table 1 presents the geotechnical characterisation carried out on both soil and rubber particles. The studied soil is defined as a high plasticity soil (noted $\mathrm{CH}$ ) according to the Unified Soil Classification System (USCS). The chemical analyses (soluble salt measures, calcium carbonate content and organic matter content) agree with the mineralogical tests previously presented.

\subsection{Effect of the rubber particles on compaction}

The Standard Proctor test and Modified Proctor test results (Fig. 2) show that the addition of rubber to the cohesive natural soil leads to decreasing the maximum dry density as well as the optimum water moisture content. This tendency is fairly linear for both maximum dry density and optimum water moisture content. The density tends to decrease as the rubber content increases with a ratio of around a $1.25 \mathrm{kN} / \mathrm{m}^{3}$ of reduction for each $10 \%$ increment of rubber. This result is similar to that previously observed by other authors (Edil and Bosscher, 1994). It is a consequence of the different specific gravity between soil and rubber particles (Higuera Seda et al., 2007). Likewise, optimum moisture content also tends to slightly drop as the content of rubber increases, due to the great difference in water absorption between soil and rubber particles. 

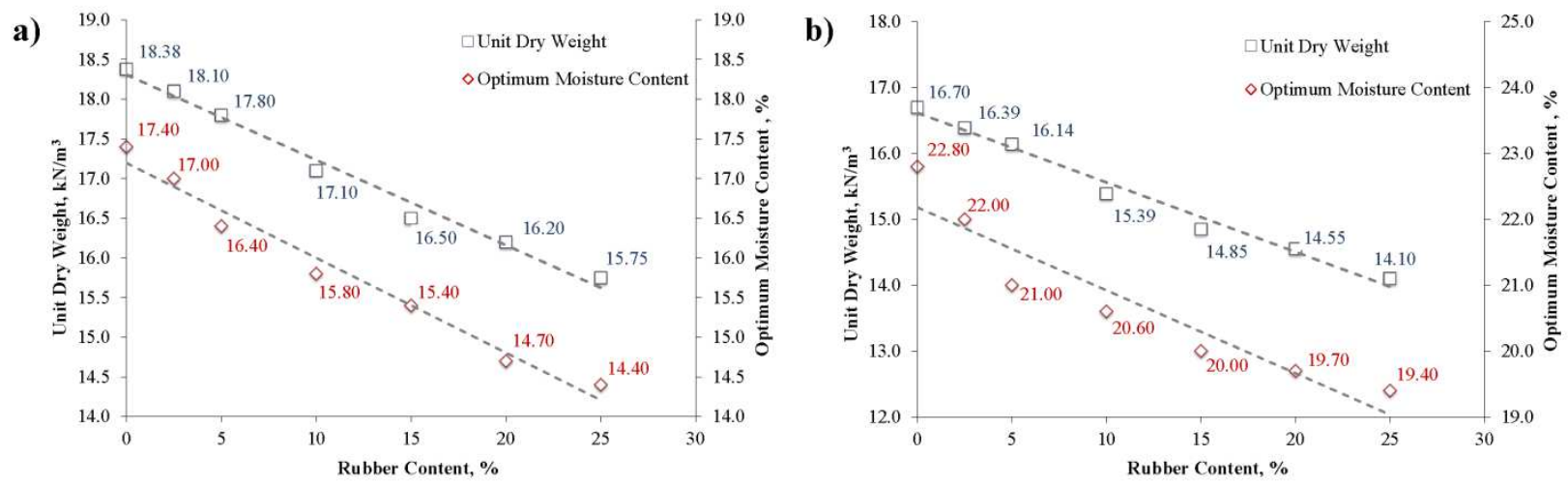

Fig. 2. Optimum characteristics for compaction tests vs rubber content: (a) Standard Proctor; (b) Modified Proctor.

\subsection{Effect of the rubber particles on free swelling}

The natural soil presents a free swelling of $3.71 \%$ in Fig. 3a. That swelling is the consequence of the presence of smectite in the sample, as confirmed by the mineralogical analysis. The presence of more than $60 \%$ of carbonated minerals explains why the swelling potential is not as high as expected for pure smectite. Moreover, soil shrinkage limit (Table 1) is not very low, and plastic index rounds 28, so swelling can be expected to be "medium" (Morilla, 2012).

The addition of rubber particles to that soil is able to prevent partially the soil from swelling linked to the smectite hydration. Rubber leads to reducing swelling and an exponential tendency is identified. That means that swelling may be significantly reduced by the addition of a small amount of rubber particles (such as the quantities considered in this paper). Hence, a $15 \%$ rubber content is able to divide by more than two the swelling potential.

\subsection{Effect of the rubber particles on compressibility}

The variation of the soil compressibility after being mixed with rubber particles can be analysed through their compression index, $\mathrm{C}_{\mathrm{c}}$, and swelling index, $\mathrm{C}_{\mathrm{s}}$, calculated from unidimensional consolidation tests. For amounts of rubber particles equal or lower to $20 \mathrm{wt} \%, \mathrm{C}_{\mathrm{c}}$ is almost constant (Fig 3b). It increases dramatically when the rubber content is extended beyond $20 \%$. On the other 
hand, $\mathrm{C}_{\mathrm{s}}$ (which is related to the elastic recovery of the soil) increases gradually along with the content of rubber, following a fairly linear behaviour. In this case, an addition up to $20 \%$ of rubber yields an increment of about $40 \%$ of such index compared with the natural soil. Results are in accordance with those found in literature for similar soil mixes (Edil and Bosscher, 1994; Tatlisoz et al., 1997; Higuera Seda et al., 2007).
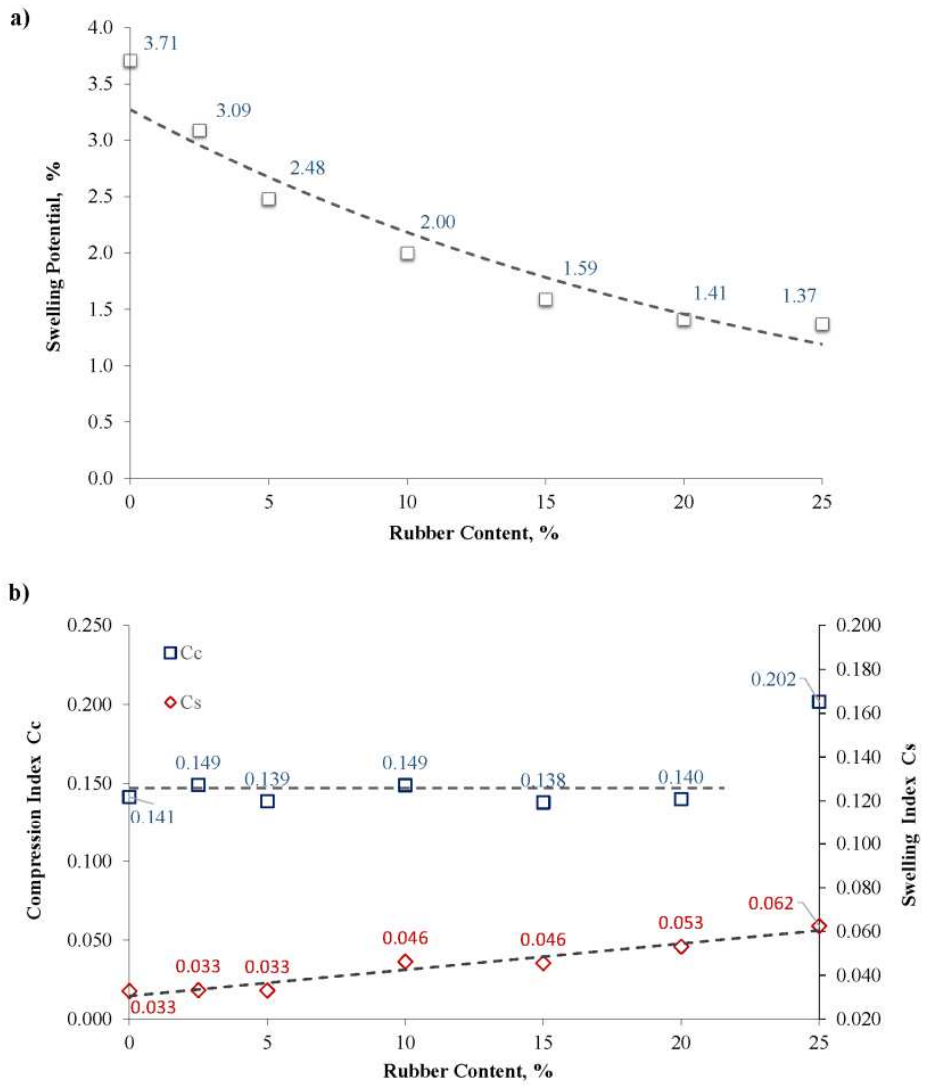

c)

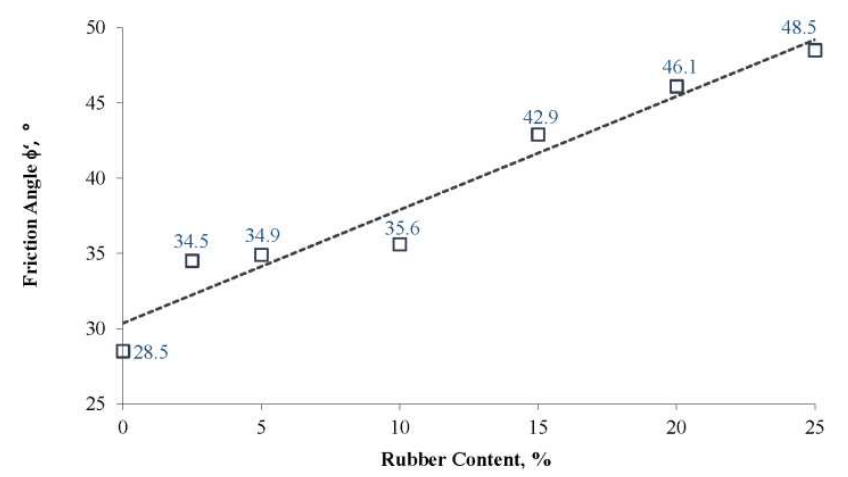

Fig. 3. Geotechnical tests: (a) swelling potential vs rubber content; (b) unidimensional consolidation tests (compressive index, $\mathrm{C}_{\mathrm{c}}$, and swelling index, $\mathrm{C}_{\mathrm{s}}$, vs rubber content); (c) friction angle vs rubber content. 


\subsection{Effect of the rubber particles on drained shear strength}

The addition of rubber particles impacts on the soil shear strength under drained conditions (Fig.

3c). The effective friction angle increases along with the rubber content, with a fairly linear tendency. For instance, the friction angle measured on a $15 \mathrm{wt} \%$ rubber-soil mix is nearly $70 \%$ larger than the one measured on the natural soil. It may come from the high friction between rubber particles when compared to that of the soil particles (Edil and Bosscher, 1994). As the tests were carried out on remoulded specimens, soil behaved as a normally consolidated soil and consequently, cohesion was null in all specimens.

Furthermore, the shear strength $v s$ horizontal displacement and vertical deformation $v s$ horizontal displacement curves are given in Fig. 4 for natural soil and the $15 \mathrm{wt} \%$ rubber-soil mix. Curves clearly confirm the tendency mentioned above and the increment in the shear strength experimented by rubber-soil mixes. Besides, rubber-soil mixes tend to experiment smaller vertical deformation, and even present some negative dilation when compared to the increasing compressibility trend observed in the natural cohesive soil (Cetin et al., 2006).

\subsection{Effect of the rubber particles on UCS}

As displayed in Fig. 5, the UCS is lower when rubber particles are added to the cohesive natural soil. Mixtures with a rubber content lower than $5 \%$ show a UCS similar to that of the natural soil (Akbulut et al, 2007), but when higher content of rubber is added UCS tends to decrease. Furthermore, even though all mixtures show a maximum peak at failure, those peaks become more flattened as the content of rubber increases. Hence, the UCS of the natural soil is $425 \mathrm{kPa}$, nearly four times larger than the value obtained for a $25 \mathrm{wt} \%$ rubber-soil mix. Conversely, axial strain at failure (i.e. at peak) increases with the addition of rubber. The natural soil reaches the point of failure with an axial strain of $6.5 \%$, barely half the deformation experimented by the $25 \mathrm{wt} \%$ rubber-soil mix. 

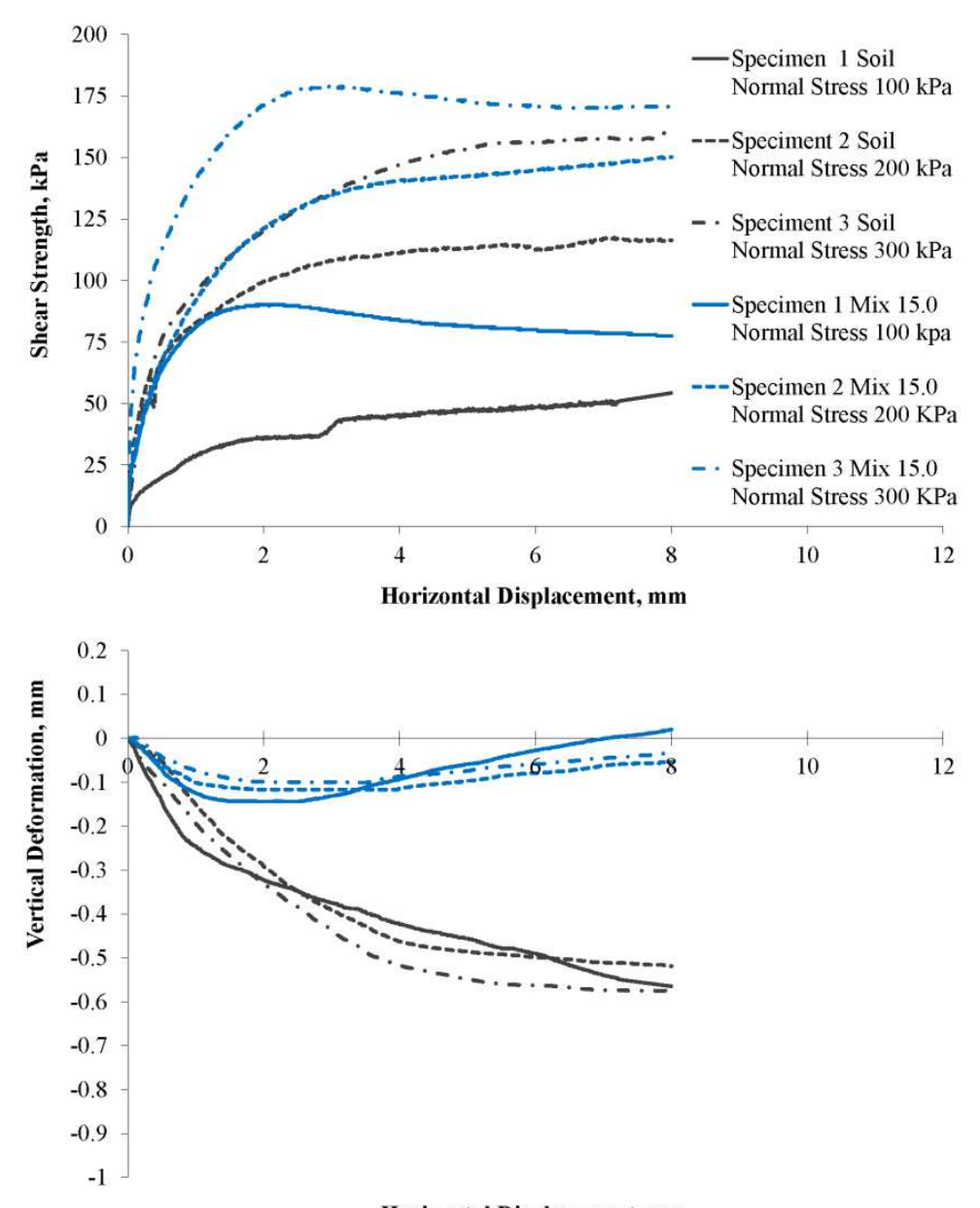

Horizontal Displacement, $\mathbf{m m}$

Fig. 4. CD direct shear tests results for natural soil and for $15 \mathrm{wt} \%$ rubber-soil mixture: (a) Shear strength vs horizontal displacement; (b) Vertical deformation vs horizontal displacement.

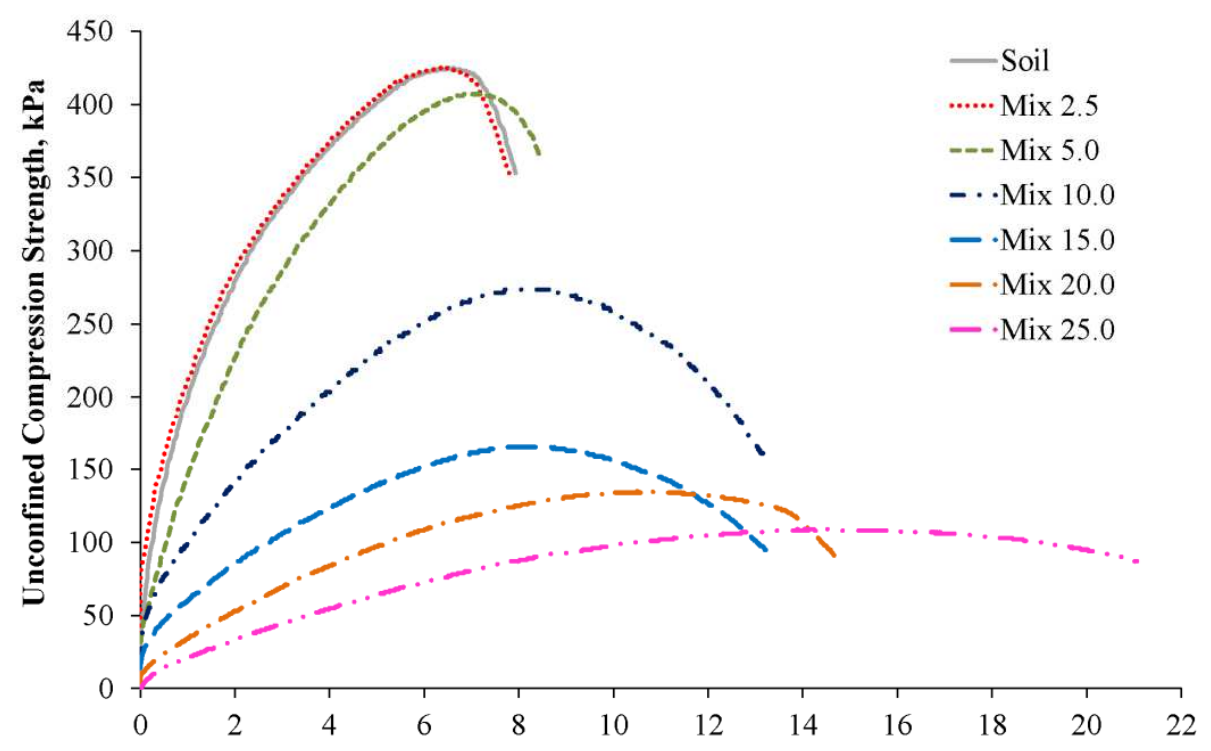

Axial Strain, \%

Fig. 5. Unconfined Compression Strength (UCS) tests results: USC vs axial strain. 


\section{Discussion}

From experimental results, the optimum content of rubber particles mixed with soil is discussed. The studied soil is a Spanish clayey soil belonging to "Facies Tap", characterized by a free swelling equal to $3.71 \%$ (as a consequence of its mineralogical composition with a $20 \%$ smectite content). Such value of free swelling potential does not fulfil Spanish standards (PG-3; PGP-2008) related to the use of material in embankment on both roads and railways. Indeed, this parameter is limited to a maximum of $3 \%$. According to Fig. 3a, this threshold value of free swelling could be reached if about $3 \mathrm{wt} \%$ of rubber particles were added to the clayey soil. The resulting rubber-soil mix would then fulfil standard requirements, thus that material would be suitable to be used as embankment. As this amount of rubber is lower than $5 \mathrm{wt} \%$, the UCS of the rubber-soil mix is not expected to be lower than UCS of natural soil (as demonstrated by experimental results), thus the addition of rubber particles to the soil should not be the origin of new instability problem. Likewise, stability issues related to drained states could be calculated as if no rubber would be added to the soil, since drained shear resistance would increase with the addition of rubber (this results contributes to increase the safety). Finally, regarding compressibility issues, the optimized proportion of rubber would provide a similar degree of compressibility to that of the natural soil, while the elastic recovery of the settlements caused by dynamic traffic loads would be slightly improved.

\section{Conclusions}

In this paper, the effects of the addition of rubber particles from scrap tyres to an expansive soil have been tested and evaluated. This is a more cost-effective and environmentally friendly solution compared to the more traditional addition of cement and/or quicklime, or the replacement of in situ soil by other. The studied soil corresponded to the "Facies Tap" soil, a typical soil present in southeastern Spain. This material is mainly composed of white argillaceous marlstone, and tends to swell, which makes difficult its use as construction material for embankments. 
Six rubber-soil mixes, with various percentages of rubber particles, $(2.5,5,10,15,20$ and 25 wt $\%)$, have been assessed and compared to the natural soil, both in terms of free swelling and other geotechnical properties, such as compressibility, drained shear resistance and undrained shear resistance.

The addition of rubber particles to the expansive clayey soil exponentially reduces swelling, and only a $15 \%$ of rubber content is necessary to decrease swelling by half. Compressibility index $\left(\mathrm{C}_{\mathrm{c}}\right)$ remains similar to that of the natural soil while rubber content is less than $15 \%$. For larger amount of rubber content, this index dramatically increases, showing that larger content of rubber would lead to a soil with high compressibility. Conversely, elastic recovery slightly increases with the addition of rubber (the tendency is fairly linear). Rubber particles influenced also the shear strength under drained conditions, because the friction angle increases its value with the addition of rubber. On the other hand, undrained shear strength decreases when the amount of rubber content exceeds 5 wt $\%$. In this case, unconfined compression strength curves become flattened and maximum strength is significantly reduced when compared to the natural soil.

From these results, the optimum rubber content in soil mixture was established at $3 \%$. For such value, the soil would be suitable for road or railway embankment and it would also keep and even improve the geotechnical properties of the natural soil. Moreover, due to the use of rubber particles from scrap tyres, the soil improvement also contributes to solve the problem of a waste management, with then subsequent environmental benefits.

\section{Acknowledgements}

The authors wish to thank the Spanish Roads Ministry for providing the soil samples as well as the EMRO company for providing the rubber particles used in this research. The authors wish also to thank Ángel Morilla Rubio and Elías Medel Perallón for their help during the tests, and Luis Fernández Pérez for his help in the geological assessment of the area of Alcoy. 


\section{References}

Akbulut, S., Arasan, S., Kalkan, E., 2007. Modification of clayey soils using scrap tire rubber and synthetic fibers. Appl Clay Sci 38, 23-32. DOI: http://dx.doi.org/10.1016/j.clay.2007.02.001

ASTM C127, 2012. Standard test method for density, relative density (specific gravity), and absorption of coarse aggregate. American Society for Testing and Materials, West Conshohocken, PA.

ASTM D1557, 2012. Standard test methods for laboratory compaction characteristics of soil using modified effort $\left(56,000 \mathrm{ft}-\mathrm{lbf} / \mathrm{ft}^{3}\left(2,700 \mathrm{kN}-\mathrm{m} / \mathrm{m}^{3}\right)\right)$. American Society for Testing and Materials, West Conshohocken, PA.

ASTM D2166/D2166M, 2013. Standard Test Method for Unconfined Compressive Strength of Cohesive Soil. American Society for Testing and Materials, West Conshohocken, PA.

ASTM D2435/D2435M, 2011. Standard Test Methods for One-Dimensional Consolidation Properties of Soils Using Incremental Loading. American Society for Testing and Materials, West Conshohocken, PA.

ASTM D2487, 2011. Standard Practice for Classification of Soils for Engineering Purposes (Unified Soil Classification System). American Society for Testing and Materials, West Conshohocken, PA.

ASTM D2974, 2013. Standard test methods for moisture, ash, and organic matter of peat and other organic soils. American Society for Testing and Materials, West Conshohocken, PA.

ASTM D3080/D3080M, 2011. Standard test method for direct shear test of soils under consolidated drained conditions. American Society for Testing and Materials, West Conshohocken, PA.

ASTM D4318, 2010. Standard test methods for liquid limit, plastic limit, and plasticity index of soils. American Society for Testing and Materials, West Conshohocken, PA.

ASTM D427, 2004. Test Method for Shrinkage Factors of Soils by the Mercury Method. American Society for Testing and Materials, West Conshohocken, PA.

ASTM D4373, 2014. Standard Test Method for Rapid Determination of Carbonate Content of Soils. American Society for Testing and Materials, West Conshohocken, PA.

ASTM D4542, 2007. Standard Test Method for Pore Water Extraction and Determination of the Soluble Salt Content of Soils by Refractometer. American Society for Testing and Materials, West Conshohocken, PA. 
ASTM D4546, 2014. Standard Test Methods for One-Dimensional Swell or Collapse of Soils. American Society for Testing and Materials, West Conshohocken, PA.

ASTM D6270, 1998. Standard practice for use of scrap tires in civil engineering applications. American Society for Testing and Materials, West Conshohocken, PA.

ASTM D6913, 2009. Standard test methods for particle size distribution (gradation) of soils using sieve analysis. American Society for Testing and Materials, West Conshohocken, PA.

ASTM D7928, 2016. Standard Test Method for Particle-Size Distribution (Gradation) of FineGrained Soils Using the Sedimentation (Hydrometer) Analysis. American Society for Testing and Materials, West Conshohocken, PA.

ASTM D698, 2012. Standard Test Methods for Laboratory Compaction Characteristics of Soil Using Standard Effort (12 $400 \mathrm{ft}-\mathrm{lbf} / \mathrm{ft}^{3}\left(600 \mathrm{kN}-\mathrm{m} / \mathrm{m}^{3}\right)$. American Society for Testing and Materials, West Conshohocken, PA.

ASTM D75/D75M, 2009. Standard practice for sampling aggregates. American Society for Testing and Materials, West Conshohocken, PA.

ASTM D854, 2014. Standard Test Methods for Specific Gravity of Soil Solids by Water Pycnometer. American Society for Testing and Materials, West Conshohocken, PA.

Barahona, E., 1974. Bricked clays in the province of Granada: evaluation of some raw materials tests. University of Granada, $\mathrm{PhD}$ Thesis (In Spanish).

Benda, C. C., 1995. Engineering properties of scrap tires used in geotechnical applications. Report $\mathrm{N}^{\circ}$ 95-1, Vermont Agency of Transportation, Montpelier, VT.

Buonanno, A., Mele, R., 2000. The use of bituminous mix sub-ballast in the Italian State Railways. 2nd Eurasphalt \& Eurobitume Congress, Barcelona, 20-22 September.

Cetin H., Fener, M., Gunaydin, O., 2006. Geotechnical properties of tire-cohesive clayey soil mixtures as a fill material. Eng Geol 88, 110-120. DOI: http://dx.doi.org/ 10.1016/j.enggeo.2006.09.002

Edil, T.B., Bosscher, P.J., 1994. Engineering Properties of Tire Chips and Soil Mixtures. Geotech Test J, 17(4), 453-464. DOI: 10.1520/GTJ10306J.

Hidalgo Signes, C., Martínez Fernández, P., Medel Perallón, E., Insa Franco, R., 2015a. Characterisation of an unbound granular mixture with waste tyre rubber for subballast layers. Mater and Struct, 48(12), 3847-3861. DOI: http://dx.doi.org/10.1617/s11527-014-0443-z. 
Hidalgo Signes, C., Martínez Fernández, P., Garrido de la Torre, M.E., Insa Franco, R., 2015b. An experimental study of a new soil-rubber mix for railway embankment. 13th Arab Structural Engineering Conference ASEC, University of Blida, Algeria, 13-15 December.

Higuera Seda, J., Lee, J.C., Carraro, J.A.H., 2007. Beneficial Use of Waste Tire Rubber for Swelling Potential Mitigation in Expansive Soils. American Society of Civil EngineersGeotechnical Special Publication 172. DOI: http://dx.doi.org/10.1061/40916(235)5.

Humphrey, D.N., Blumenthal, M., 2010. The Use of Tire-Derived Aggregate in Road Construction Applications. Green Streets and Highways 2010, 299-313.

Long N.T., Delmas P., Pouget, P., 1984. Characteristics and application of use scrap tyres. Bulletin de Liaison des Laboratoires des Ponts et Chaussées, nº 129 (In French).

Mahdi Hejazi, S., Sheikhzadeh, M., Mahdi Abtahi, S., Zadhoush, A., 2012. A simple review of soil reinforcement by using natural and synthetic fibers. Constr Build Mater 30, 100-116. DOI: http://dx.doi.org/10.1016/j.conbuildmat.2011.11.045.

Moore, D. M., Reynolds, R. C. Jr., 1989. X-Ray Diffraction and the Identification and Analysis of Clay Minerals. Oxford University Press, Nueva York.

Morilla, I., 2012. Soil Tests Geotechnical Interpretation. Garceta, Madrid (In Spanish).

Nelson, J.D., Miller, D.J., 1992. Expansive Soils: Problems and Practice in Foundation and Pavement Engineering. John Wiley and Sons, Inc., New York.

PG-3, 2002. Technical Specifications for Road and Bridges Projects. Spanish Ministry of Public Works and Transport, Madrid (In Spanish).

PGP-2008, 2008. Technical Specifications for Railway Platform Projects. ADIF, Railway infrastructure administrator, Madrid (In Spanish).

Środoń, J., 1984. X-ray powder diffraction identification of illitic materials. Clay Clay Miner, 32, 337-349.

Steinberg M., 1998. Geomembranes and the Control of Expansive Soils in Construction. McGrawHill, New York.

Tatlisoz, N., Benson, C.H., Edil, T.B., 1997. Effect of fines on mechanical properties of soil-tire chip mixtures. In: Wasemiller MA, Hoddinott KB (editors), Testing soil mixed with waste or recycled materials. ASTM Special Technical Publication 1275, American Society for Testing and Materials. 
Trouzine, H., Bekhiti, M., Asroun, A., 2012. Effects of scrap tyre rubber fibre on swelling behavior of two clayey soils in Algeria, Geosynthetics International, 19(2), 124-132.

Wolfe, S.L., Humphrey, D.N., Wetzel, E.A., 2004. Development of tire shred underlayment to reduce groundborne vibration from LRT track. Geotechnical engineering for transportation projects: Proceedings of the Geo-Trans 2004, 750-759. 